\title{
The dark side of phrónēsis: revisiting the political incompetence of philosophy
}

\author{
BRUCE KRAJEWSKI \\ Texas Woman's University \\ EUA
}

Aвstract. In his Ethics, Aristotle joins sōphrosunē and phrónēsis as synonyms. In approximately the same time frame, Xenophon provides a Wittgensteinian account of a go-and-look instance of what sōphrosunē looked like in one ancient Greek context. We have a disturbing description of sōphrosunē in action. It leaves a reader with quite a different picture of the meaning of these two key words from the staid, peaceful, deliberative contemporary interpretations, particularly in Continental philosophy, that attempt to make both phrónēsis and sōphrosunē the foundation for a praiseworthy ethics and politics. Continental philosophers like Martin Heidegger and Hans-Georg Gadamer attended closely to Aristotelian phrónēsis (not the Xenophonic variety), but were unable to put that learning into practice in their own ethical and political lives, making one wonder why followers of Heidegger and Gadamer continue to insist on ethical programs based in the Heideggerian and Gadamerian phronetic tradition, where Aristotle has supplanted Odysseus as the model most associated with phrónēsis and sōphrosunē.

Keywords. Phrónēsis; sōphrosunē; Aristotle; Xenophon; prudence; Gadamer; Heidegger; National Socialism; esotericism.

Wie steht der Philosoph zu der politischen und gesellschaftlichen Wirklichkeit? / Where do philosophers stand in relation to political and social reality?

- Hans-Georg Gadamer, On the political incompetence of philosophy ${ }^{1}$

Phronesis ist immer Unterscheidung und Wahl dessen, was man für das richtige hält. / Phronēsis is always the process of distinguishing and choosing what one considers to be right.

- Hans Georg-Gadamer, letter to Richard Bernstein ${ }^{2}$

Email: bkrajewski@mail.twu.edu

${ }^{1}$ Hans-Georg Gadamer, "Über die politische Imkompetenz [sic] der Philosophie," Hermeneutische Entwürfe (Tübingen: Mohr Siebeck, 2000), 35; "On the Political Incompetence of Philosophy," Diogenes, No. 182, 46/2 (Summer 1998): 3.

${ }^{2}$ Richard J. Bernstein, Beyond Objectivism and Relativism: Science, Hermeneutics, and Praxis (Philadelphia: University of Pennsylvania Press, 1983), 264-65. 
Orpheus gave the name, Moira, to phrónēsis, intelligence...

The history of phrónēsis and sōphrosunē, two words linked by Aristotle in his Ethics (1140b), deserves closer attention, especially given the ethical importance classicists and philosophers have given these two words in both the rhetorical and philosophical traditions. A monolithic consensus has formed around the contemporary understanding of phrónessis that belies the origins found in Xenophon's account (Constitution of the Lacedaimonians III.3-6) of sōphrosune as reported by Jean-Pierre Vernant and Pierre Vidal-Naquet, ${ }^{4}$ an account that is roughly contemporaneous with Aristotle's Ethics. Scholars on the side of the monolithic view claim the two words are about practical wisdom, temperance, prudence, forbearance, orderly behavior, self-possession, keeping one's discernment intact, exhibiting discretion, hitting the mark with right action, uncovering the truth in action, and a host of other virtuous-sounding synonyms. This monolithic view has been adopted by people in numerous disciplines, so that one can find scholarly articles that map phrónessis on to educational and business leadership, medical training, urban planning, and political science, giving the impression of a renaissance in the past 100 years of Aristotle's terms.

My aim, in part, will be to trace the renaissance, to focus on a recent appropriation of these terms by the classicist and philosopher Hans-Georg Gadamer, who, according to Fred Lawrence, "makes phrónēsis the heart of his philosophical hermeneutics." The catalyst for Gadamer's attention to phrónessis is Martin Heidegger, Gadamer's teacher and the man who "recovered Aristotle's Rhetoric for philosophy" via an "extraordinary lecture course at Marburg in the Summer Semester of 1924." ${ }^{\prime 6}$ Smith, Dennis J. Schmidt, Fred Lawrence, Ronald Beiner, Jean Grondin, Gerald Bruns,

${ }^{3}$ Marcel Detienne and Jean-Pierre Vernant, Cunning Intelligence in Greek Culture and Society, trans. Janet Lloyd (Atlantic Highlands, NJ: Humanities Press, 1978), 138.

${ }^{4}$ Jean Pierre-Vernant and Pierre Vidal-Naquet, Myth and Tragedy in Ancient Greece, trans. Janet Lloyd (Boston: Zone Books, 1990), 198.

${ }_{5}^{5}$ The Cambridge Companion to Gadamer, ed. Robert J. Dostal (New York: Cambridge University Press, 2002), 180.

${ }^{6}$ P. Christopher Smith, "The Uses and Abuses of Aristotle's Rhetoric in Heidegger's Fundamental Ontology: The Lecture Course, Summer, 1924" in From Phenomenology to Thought, Errancy, and Desire, ed. Babette Babich (Dodrecht: Kluwer Academic, 1995), 316. Gadamer says that Heidegger's seminar on phrónēsis took place in the summer of 1923. See "Heidegger as Rhetor: Hans-Georg Gadamer Interviewed by Ansgar Kemmann" in Heidegger and Rhetoric, eds. Daniel Gross and Ansgar Kemmann (SUNY Press, 2005), 48. 
Richard Bernstein, Lawrence Schmidt, Georgia Warnke, and numerous other disciples of Heidegger and Gadamer consider Gadamer's take on phrónēsis, based in part on Heidegger's work, as utterly salutary and salubrious. This essay will suggest that the forgotten (suppressed?) account of phrónēsis and sōphrosunē in Xenophon represents a dark, devious, patriarchal ${ }^{7}$ reception history that calls out for undoing.

The narrative that most call the history of philosophical hermeneutics includes some unappealing parts, moments of praxis that do not correspond to the theory, human events that generate questions, defensiveness, controversy, perhaps even embarrassment. Jonathan Lear reminds us that the cloth of history ends up with holes and stains. "While the tradition will present a homogeneous story of inheritance and development, in fact that story will be covering over a series of ruptures, discontinuities, and evasions." " Hans-Georg Gadamer's self-confessed "incompetence" about politics is one of those parts that might be a rupture, a discontinuity, and an evasion. Until that essay about philosophical competence made its appearance late in Gadamer's life, one narrative linked to philosophical hermeneutics had remained relatively stable, continuous, and that was the story of phrónēsis. In the 1920s in a seminar Martin Heidegger gave on the Nichomachean Ethics, Gadamer witnessed Heidegger cementing of phrónēsis to conscience. Phrónēsis played a significant role in Gadamer's first major study of Plato (Plato's Dialectical Ethics, 1931) and a crucial role in Truth and Method (1960). The word has now become a staple in Gadamerian scholarship. In an article in the collection titled Feminist Interpretations of Hans-Georg Gadamer Robin Pappas and William Cowling describe phrónessis as "ethical know-how," "the modality according to which understanding functions as an ethical practice." It has something to do with "reflective awareness." Pappas and Cowling note that Gadamer's writings about phrónesis do not seem to address the role that marginalized groups would have in this "modality." Pappas and Cowling admit no other "modality" for achieving political change, and end up replicating Gad-

\footnotetext{
${ }^{7}$ Christopher P. Long, "The Daughters of Metis: Patriarchal Dominion and the Politics of the Between" in Graduate Faculty Philosophy Journal, Vol. 28, No. 2 (2007). It's the first part of this article that fits my purposes, not the accommodating second half of the piece, which attempts to locate an alleged middle way.

${ }^{8}$ Jonathan Lear, "Give Dora a Break!: A Tale of Eros and Emotional Disruption" in Erotikon: Essays on Eros, Ancient and Modern, eds. Shadi Bartsch and Thomas Bartscherer (Chicago: University of Chicago Press, 2005), 197.

${ }^{9}$ See their "Toward a Critical Hermeneutics" in Feminist Interpretations of Hans-Georg Gadamer, ed. Lorraine Code (University Park, PA: Penn State University Press, 2003), 211.
} 
amer's position that requires that conversation remain the fundamental element for political change. The ancient issue of bia versus logos does not enter into their conversation.

Gerald Bruns asserts that "Gadamer's account of phrónēsis goes on explicitly in terms of the actions of a situated moral agent involved with other people." ${ }^{\prime 10}$ Joseph Dunne corroborates that reading by pointing out that Gadamer's explication of the term in Truth and Method indicates that phrónēsis is "realized always in concrete applications," and is "perhaps the fundamental form of experience." Following Aristotle, Gadamer argued that phrónēsis contains an ethical dimension. In fact, in his writings about phrónēsis and in the commentaries, phrónēsis inevitably is bound up with virtue, with choosing the good, the true, the correct, the proper. ${ }^{11}$

Yet, Gadamer's concrete experiences during the Second World War and after, when one could argue that he was most importantly "a situated moral agent involved with other people," in circumstances that called for "ethical know-how" and Aristotelian arete - those experiences become precisely the sites of discontinuities, evasions, and declarations of "incompetence." Those are the moments one would expect to be exemplary for witnessing phrónésis on display, and they are, and they are not. To put it another way, the exoteric phrónēsis failed, but the esoteric phrónēsis succeeded, and continues to succeed as philosophers and literary critics still look to Heidegger and Gadamer for guidance about phrónēsis, even after one of them has declared himself "incompetent" on the subject.

My experience has been that scholars who work on hermeneutics become dismissive or reactionary when confronted with the concrete experiences of Heidegger and Gadamer mentioned above and below. These discontinuities and ruptures in the stories of philosophical hermeneutics and phrónēsis tend to be seen negatively, not as opportunities for recon-

${ }^{10}$ Gerald L. Bruns, Tragic Thoughts at the End of Philosophy: Language, Literature, and Ethical Theory (Evanston: Northwestern University Press, 1999), p. 119. See also JosEPH Dunne, Back to the Rough Ground: Practical Judgment and the Lure of Technique (Notre Dame: Notre Dame University Press, 1993), esp. 126-27.

${ }^{11}$ Hans-Georg Gadamer, Truth and Method, trans. Joel Weinsheimer and Donald G. Marshall (New York: Continuum, 1989), 22 and 312. Robin Pappas and William Cowling describe phrónēsis as "ethical know-how", "the modality according to which understanding functions as an ethical practice." It has something to do with "reflective awareness." See also Dennis J. Schmidt, "On the Incalculable: Language and Freedom from a Hermeneutic Point of View" in Research in Phenomenology 34 (2004), in which he writes: "I want to claim that we should see that hermeneutics makes an original contribution to the task of thinking the realm of the ethical in a manner that highlights both the kinship and the difference between Gadamer and Heidegger" (34). 
sideration, for proceeding in a new way that better addresses the current situation of the situated moral agents around us who live in a post-capitalist world lacking a global political solution to that post-capitalism, in a liberal-democratic affluent society that has no significant plan for addressing poverty elsewhere, in a North American culture that thinks the highest expression of political acumen is laughing at the bits on The Daily Show. In short, the situation is not much different from The House of Mirth.

\section{Philosophical Autism}

For Germans, the years 1930 through 1950 constitute a period of collective amnesia, or at least what Hans Magnus Enzensberger calls "insensibility." That period in German history may come to rival the first decade of the $21^{\text {st }}$ century in American history, but that latter narrative has not played itself out. One of my prooftexts here is W.G. Sebald's The Natural History of Destruction, ${ }^{12}$ a book that contains a series of lectures about the Allied bombings of German cities during World War II and the surprisingly silent, rebuilding of those cities. Sebald wondered about the autism of those decades in which people functioned assiduously in the face of devastating attacks and in the face of debris and destruction that must have seemed overwhelming. Why was it not possible to point to important German writing from that period that addressed the matter that was in plain sight everyday in the streets? Sebald writes, "To the overwhelming majority of the writers who stayed on in Germany under the Third Reich, the redefinition of their idea of themselves after 1945 was a more urgent business than depiction of the real conditions surrounding them." ${ }^{13} \mathrm{We}$ ought to be able to replace the word "philosophers" where "writers" is in the previous sentence, because we have prominent instances of personal reconstructions that took place in the cases of Heidegger and Gadamer.

That comment from Sebald echoes the opening of Gadamer's essay entitled "On the Political Incompetence of Philosophy," which was written in 1992/93, according to Gadamer, and is interestingly misspelled in the title of the 2000 edition of the essay. There it is "Imkompetenz." ${ }^{\prime 14}$ In that

${ }^{12}$ W.G. Sebald, On the Natural History of Destruction, trans. Anthea Bell (New York: Random House, 2003).

${ }^{13}$ Ibid., ix.

14 "Incompetence" is, of course, the negation of competence, whose root has to do with competition. In the negative form, it could mean the end of a rivalry or the end of a vying for position. The $O E D$ tells its readers about a 1623 usage connected to property. The dictionary cites the phrase "a competence of land." "Incompetence" in the sense that Ga- 
opening bordering on despair, Gadamer wonders what philosophers can offer the general population in its efforts to come to terms with reality, as if he had forgotten Plato's allegory of the cave. While Gadamer will be my prime suspect here, one need only recall that such amnesia and autism (a word strategically chosen to create discomfort) did not affect everyone between 1930 and 1950. Someone who loomed larger than Gadamer, namely Heidegger, also had more public difficulties on this score, though he was in contact with someone who was, by some accounts, obsessed with remembering the events between 1930 and 1950, to the point that family and friends reported that it affected his mental stability. That person is Paul Celan..$^{15}$ The added twist to my account here involves the fashioning and acceptance of a false (or at least as yet unverified) history about an event that took place after 1950, a key moment for those who study Continental philosophy and German literature, the publication of Celan's "Todtnauberg" poem.

As James Lyon describes it in his book ${ }^{16}$ Paul Celan and Martin Heidegger: An Unresolved Conversation, 1951-1970, Celan and Heidegger read one another's works, partly through each sending copies of publications to the other. They would discuss their writings when the two would meet. The famous 1967 Todtnauberg meeting was not the only one between the two men, and it was not even the only one of that year, though it seems to have been the one most misinterpreted. The standard interpretation of the meeting is that Celan, at long last, confronted Heidegger about Heidegger's participation in National Socialism, and that Celan left without a satisfying response from Heidegger, but with a silence from Heidegger that further confirmed his guilt. ${ }^{17}$ According to Lyon, who has completed an extensive study of the available documentation, "there is not a shred of documented biographical evidence from their entire time together to sug-

damer conveys does not come along in English until the late $18^{\text {th }}$ century. In the medical sense, "competence" is about normal functioning. Thus, reinterpreting Gadamer's essay's title with this medical context in mind, one could say that the title points us to the fact that when philosophers are involved in politics, they do not function normally.

${ }^{15} \mathrm{He}$ was born Paul Antschel.

${ }^{16}$ James K. Lyon, Paul Celan and Martin Heidegger: An Unresolved Conversation, 19511970 (Baltimore: Johns Hopkins University Press, 2006). One must be careful with Lyon's book. Immersed in Heidegger and Celan, Lyon finds at every turn in Celan's writings parallels and allusions to Heidegger that sometimes exclude other obvious alternatives (e.g. "Einbahnstrassen" is not linked to Walter Benjamin, but to Heidegger, 115).

${ }^{17}$ A forcefully expressed synopsis of what has become the standard view of the CelanHeidegger meeting can be found in Steven Ungar's Scandal and Aftereffect: Blanchot and France since 1930 (Minneapolis: University of Minnesota Press, 1995), 63. 
gest that Celan condemned Heidegger." ${ }^{\prime 8}$ Lyon concludes by saying that "most readers have distorted the content of the poem ["Todtnauberg"] and the entire relationship that preceded and followed it." ${ }^{\prime \prime}$ Forty years later, Lyon provides the potion to awaken us from the standard reading of an event that likely cannot withstand the cultural pressure that has been placed upon it, especially given the elliptical nature of Celan's poem.

How could it happen that so many people, especially intellectuals trained in reading, could have gone wrong about "Todtnauberg"? One can imagine the motivations of those who require a good against evil scenario here, with Heidegger aligned with Hitler, and Celan with the forces of light and victimhood, a scenario that occludes access to Celan's enthrallment with Heidegger, and to Celan's inheritance of Nietzschean symptoms. This is not to say that Lyon has laid the matter to rest, and solved a problem. What problem? Will Lyon's evidence displace the conventional reading of "Todtnauberg"? Many people still read Frost's "The Road Not Taken" as a lesson in the value of choosing the more difficult path, despite internal evidence that the traveler would like to have taken both roads, and that both paths were worn "really about the same." ${ }^{20}$ Adjusting our hermeneutical compass about well-worn poems is not the point. We need to be after the exoteric and esoteric causes of the confusion - the words, the surface, and the historical context which includes the ongoing inability of philosophical hermeneutics and almost all other forms of contemporary interpretation to cope with esotericism. ${ }^{21}$

Lyon supplies the case to answer this question about why the right road has not been taken due to the words of "Todtnauberg." Celan read Heidegger carefully, borrowing Heidegger's language monotonously. Heidegger's neologisms had a magnetic effect on Celan, according to Lyon. One might guess that such intertextuality, mapped in detail by Lyon, would result in some linguistic effects that would be commonly attributed to both writers. We need not review the vitriolic attacks on Heidegger's prose (the translations do not fare better), ${ }^{22}$ but the vices of

\footnotetext{
${ }^{18}$ Ibid., 169.

${ }^{19}$ Ibid., 172.

${ }^{20}$ Richard Strier deserves the credit for reading the words on the page.

${ }^{21}$ See Geoff Waite, "On Esotericism: Heidegger and/or Cassirer at Davos," Political Theory 26.5 (1998): 603-51. For this thread in relation to Plato, see HANS JOACHIM KRÄMER, Plato and the Foundations of Metaphysics: A Work on the Theory of the Principles and Unwritten Doctrines of Plato with a Collection of the Fundamental Documents, ed. and trans. John Catan (SUNY Press, 1990).

${ }^{22}$ Anything by Simon Blackburn on Heidegger will do as evidence.
} 
style in Heidegger become virtues for the poet Celan. Gerald Bruns, one of our best hermeneutical readers of opaque poetry, writes of Celan's poetry this way, and remember that Bruns intends for the following characterization to be positive: Celan's are "poems in which the given is dismembered and recombined into unrecognizable forms." ${ }^{23}$ Bruns serves as an excellent case in point here, because he has studied both Celan and Heidegger, and Bruns recognizes that Heidegger is deliberate in "writing darkly, hermetically," ${ }^{24}$ though Bruns does not follow that recognition to its darkest political corners. ${ }^{25}$ That is part of my task here. Before continuing, I should say that Bruns is not another in a long line of apologists for Heidegger. Bruns accepts the consequences of taking up Heidegger: "So we must imagine Heidegger's action [Heidegger's endorsement of Hitler] spreading across the text of philosophy like a deep stain; and not only across the text but also across the hands that take it up for study."

\section{Plato's Unwritten Philosophy, Nietzsche's Shadow}

Philosophical hermeneutics has constituted itself by way of the word, but has yet to come to grips with its own inheritance of esotericism that begins with Plato and has been ratcheted up in its effectiveness and virulence by Friedrich Nietzsche, a thinker crucial for reading Heidegger, Celan, and Gadamer. ${ }^{26}$ Lyon writes of how Heidegger's two-volume lecture series on Nietzsche served as a catalyst for Celan's unfortunate self-identification with Nietzsche. ${ }^{27}$ Gadamer himself notes the global impact that Nietzsche has had. ${ }^{28}$ All of this should remind us that Leo Strauss' claim continues

\footnotetext{
${ }^{23}$ Gerald L. Bruns, On the Anarchy of Poetry and Philosophy: A Guide for the Unruly (New York: Fordham University Press, 2006), 48.

${ }^{24}$ Gerald L. Bruns, Heidegger's Estrangements: Language, Truth, and Poetry in the Later Writings (New Haven: Yale University Press, 1989), xv.

${ }^{25}$ Ibid., 15.

${ }^{26}$ For some of the crucial ways Gadamer has been infected by Nietzsche, see GeofF WAITE, "Radio Nietzsche, or, How to Fall Short of Philosophy" in Gadamer's Repercussions: Reconsidering Philosophical Hermeneutics, ed. Bruce Krajewski (University of California Press, 2004), 169-211. Waite's Nietzsche's Corps/e: Aesthetics, Politics, Prophecy, or, the Spectacular Technoculture of Everyday Life (Durham: Duke University Press, 1996) is essential reading.

${ }^{27}$ LyON, 140-41.

${ }^{28}$ Gadamer in Conversation: Reflections and Commentary, ed. and trans. Richard Palmer (New Haven: Yale University Press, 2001), 98. Gadamer: "This is what in fact amazes me in the Nietzsche revival, both in France and in the rest of the world. With the rich cultural heritage that we have, it [the Nietzsche revival] still creates all these tensions today that people believe we have not resolved." The "we" must mean "philosophers."
} 
to be true: "The distinction between exoteric (or public) and esoteric (or secret) teaching is not at present considered to be of any significance for the understanding of the thought of the past...." ${ }^{29}$ My own experience with scholars who consider themselves Gadamerians confirms that Strauss' assertion is, for the most part, accurate.

One scholar who has directed our attention to Gadamer's own role in this esoteric tradition is Robert Sullivan, though he too comes up short in confronting the matter. Sullivan translated into English Gadamer's Philosophische Lehrjahre, and has an appreciation for the connection between Gadamer's political positions and Gadamer's studies of Plato, with the Seventh Letter casting a shadow over Gadamer's publications on Plato. As we shall see, it is no accident that Plato's dialogues and Plato's Seventh Letter were foundational texts for Gadamer, both in the early part of his career, which included scholarly publications and addresses on Plato during the National Socialist period, and in Gadamer's responses in the late 1980's and early 90's to Victor Farias' book on Heidegger. References to Plato's Seventh Letter appear in two important essays from that period, "Back from Syracuse?" 30 and "On the Political Incompetence of Philosophy."

One of the opening rhetorical gestures Gadamer displays in the "Back from Syracuse?" essay is a yawn in the face of international scandal. This gesture positions Gadamer above those who were energized and outraged at the time by Farias' book. Gadamer writes: "In the German-speaking lands, almost all of what Farias reports has long been known.. ${ }^{31}$ By seeking to undo the shock value of Farias' book, Gadamer begins a narrative meant to normalize accommodations to National Socialism. The idea seems to be that Gadamer and others of his generation who lived through the period would not find anything astonishing in Farias' book, because Heidegger's actions and inactions described therein would not be construed as extraordinary. Those actions and inactions were part of a massive "self-deception," as Gadamer calls it, one extending implicitly to the majority of Germans during that time. In the second paragraph, Gadamer decides to address the generation of Germans who did not live during the Second World War, and who would "not have an easy time imagining how things were with us in

${ }^{29}$ Leo Strauss, "Exoteric Teaching" in The Rebirth of Classical Political Rationalism (Chicago: University of Chicago Press, 1989), 63.

${ }^{30}$ Hans-Georg Gadamer, "Back from Syracuse?", trans. John McCumber in Critical Inquiry 15 (Winter 1989): 427-30. The essay appeared originally in Le Nouvel Observateur in 1988. “Zurück von Syrakus?" in J. ATwEGG (ed.), Die Heidegger Kontroverse (Frankfurt: Athenäum, 1988), 176-79.

${ }^{31}$ Ibid., 427. 
those days: the wave of conformism, the pressure, the ideological indoctrination...." ${ }^{32}$ What could philosophers do in such a situation? Heidegger would be no different from anyone else in similar circumstances, according to this view, one reiterated in the "Incompetence" essay. There Gadamer writes, "We all run the risk of harboring illusions and getting things wrong." ${ }^{33}$ This universal capacity for wrongness - a kind of anti-phrónēsis - becomes a theme in the essay. Gadamer tells the reader, "We ought not to be surprised [sollten ... nicht wundern] that a man [Heidegger] endowed with the power of superior thought can be mistaken," ${ }^{34}$ and then in the same paragraph add: "It is hardly surprising [Es kann kaum verwundern] that a great thinker should get it so badly wrong." ${ }^{35}$ Implicitly, Gadamer acknowledges that many people have been surprised, astonished. Gadamer apparently viewed his role, in part, as calming the waters, undoing the surprise, saying something like, this is what one should expect, stop being surprised about Farias' book, nothing in Heidegger's work prepared us for thinking he could be (despite his attention to phrónessis) an exception to the mass abandonment of ethical positions that would have countered National Socialism in full consciousness of the range of potential consequences. If we are to accept Gadamer's description of the historical moment that included the years 1933-45, the conditions at that time could not permit a Socrates, a person interested in philosophy who could have said "no," due to the "ideological indoctrination" and other factors. In the "Back from Syracuse?" essay, Gadamer emphasizes the "tendency ... to underestimate the universally human inclination to conformism, which continually finds new ways and means for self-deception." ${ }^{\prime 36}$ That must mean that the example of Socrates from the Seventh Letter had been forgotten. In the Seventh Letter, we are told that "Socrates, so far from obeying, was prepared to risk everything rather than participate in their infamous deeds" (325a). It should then not be surprising when someone like Robert Sullivan writes, "Gadamer the man was an opportunist who in the 1930s repeatedly accommodated himself to the regime for the sake of advancing his career." ${ }^{37}$ While this bothers Sullivan to a degree, he sidesteps the issue on two fronts - first, by deciding that he will bracket the man from the thinker, and sec-

${ }^{32}$ Ibid., 427.

${ }^{33}$ Gadamer, "Political Incompetence," 7.

${ }^{34}$ Ibid., 8.

${ }^{35}$ Ibid., 9.

${ }^{36}$ GADAmer, "Back from Syracuse?", 427.

${ }^{37}$ Robert Sullivan, "Gadamer and National Socialism: A Response to Richard Wolin," Internationale Zeitschrift für Philosophie (2001/1): 56. 
ond by excluding from his narrative the "prudent" moves Gadamer made for his career when the Second World War ended and Gadamer in 1947 was elected rector of the University of Leipzig, which was under Soviet control. As Jean Grondin relates, "The Russians viewed him [Gadamer] as a cooperative, practical man, interested in working with them. ${ }^{{ }^{38}} \mathrm{Un}-$ like Heidegger, Gadamer had not only National Socialist opportunism for which to answer, but also Stalinist. In defending Heidegger by declaring his flawed humanity and vulnerability to conformity, and by undermining a sense of surprise about thinkers who succumbed to plainly questionable acts, Gadamer prepared his own defense for those who might wonder how Gadamer could ever reconcile his conformity to both National Socialism and to Soviet communism.

Rest assured that almost no North American scholars of Gadamer's work lose sleep over these examples of Gadamerian phrónēsis, a.k.a. conformity, adjustment, collaboration, accommodation, opportunism, careerism, trickery - all the synonyms for the dark side of phrónēsis. Grondin deserves special mention for the prose used on the dust jacket for the English translation of his biography of Gadamer. We learn there that Gadamer was "at the center of some of the century's darkest, most complex historical events, for he chose to remain in his native Germany in the 1930s, neither supporting Hitler nor actively opposing him, but negotiating instead an unpolitical [note that the word used is not apolitical] position that allowed him to continue his philosophical work." Now, this is surprising. Grondin must perform some Cirque du Soleil-like moves, for instance, to draw readers' attention away from a "Heil Hitler!" that Gadamer uses to end a 1940 letter to one of his colleagues..$^{39}$ According to Grondin, such closings were routine, "although not mandatory." The evidence forces Grondin to admit that "Gadamer was not a frontline member of the resistance" ${ }^{\text {"40 }}$ during the National Socialist period, which seems to suggest that he was part of "the resistance," just not at the front, but if that were the case, then we would have to remove the word "unpolitical" on the book's publicity materials. Perhaps Grondin realized his problem of logical consistency, and thus we have this statement: "[Gadamer] saw his own task of resistance in a different way, however: as a teacher of philosophy he needed to keep the tradi-

38 Jean Grondin, Hans-Georg Gadamer: A Biography (New Haven: Yale University Press, 2003), 240; Grondin, Hans-Georg Gadamer: Eine Biographie (Tübingen: Mohr Siebeck, 1999), 270: "Die russischen Machthaber sahen offenbar in ihm einen sachlichen Mann, mit dem sie zusammenarbeiten konnten."

${ }^{39}$ Ibid., 212 in English edition, 240 in German.

${ }^{40}$ Ibid., 224 in English edition, 254 in German. 
tion of thought alive, so that people could return to it after the nightmare [Alptraum] was over." ${ }^{\prime 41}$ This tradition is most likely the Platonic esoteric tradition, revealed in part in the Seventh Letter.

Grondin's verbal gymnastics on behalf of Gadamer suggest that Grondin too partakes of esotericism. He will cloak Gadamer in illogical virtue. One is "unpolitical," while at the same time part of a "resistance," but not "on the front line of that resistance." One can conclude a letter with "Heil Hitler!," and at the same time do it out of innocent "routine." Clearly, it was not done out of routine resistance, and certainly never on the frontline of that resistance. In short, we cannot take the words at face value. The resistance is invisible and cannot be located in the words, which are not there, and they are not there because it was not safe; Gadamer, unlike Socrates, was not prepared to risk everything. We are now in position to return to a later portion of Plato's Seventh Letter ${ }^{42}$ in which we find a principle that will be followed by a wise man in his behavior toward his own state: "If he thinks anything amiss with its government he will speak out, provided that his words are not going to be wasted or to bring him to his death, but he will not attempt to change the constitution of his native land by force." ${ }^{43}$ The circumstances must be right for virtue, for resistance. Rhetorically, one needs to be attuned to kairos, kairos in its meaning from the history of rhetoric, not the Christian kairos. If the conditions are not ideal, this tradition provides guidance about pulling up short of using force. Grondin seems to accept this view. It was up to other people to take the risks, to exert the force, to make the sacrifices, to defeat National Socialism, to end the Alptraum. Somehow others were able to overcome the ideological indoctrination, the conformity, the routine, the insensibility of those times. How did they do it without phrónēsis?

Plato reports in the Seventh Letter that he and his friends did not want to communicate plainly their ideas about ruling justly. "We did not use such plain language as this - it was not safe to do so - but we succeeded by using riddles [ainittomenoi] in maintaining the thesis that every man who would preserve himself and the people he rules must follow this course, and that any other will lead to utter destruction" (332d). See also 341c about treatises that will never exist. The deliberate use of riddles,

${ }^{41}$ Ibid.

${ }^{42}$ Hans-Georg Gadamer, "Dialectic and Sophism in Plato's Seventh Letter," in Dialogue and Dialectic: Eight Hermeneutical Studies on Plato, trans. P. Christopher Smith (New Haven: Yale University Press, 1980), 96. See F. M. Cornford, The Unwritten Philosophy and Other Essays (Cambridge: Cambridge University Press, 1967), esp. 32.

${ }^{43}$ Gadamer, "Dialectic and Sophism," 331. 
dark language, hermetic writing - all count as signs of esotericism, and of the dark side of phrónēsis.

It is time now to attend to the pre-Platonic history of phrónēsis mapped partially by Marcel Detienne and Jean-Pierre Vernant, who emphasize the relationship of phrónēsis and mêtis (cunning intelligence conjure Odysseus here), the latter term seeming more appropriate to the attempted exculpatory characterizations formulated by Grondin of Gadamer's actions and inactions between 1930 and 1950. In the pre-Platonic context of the word, phrónēsis involves not "self-deception," but foresight, an ability not only to imagine a future, but also to bring it about cleverly.

The papyrus from Derveni provides valuable confirmation on this point [a section that uses weaving as a model of intelligent and generative activity]. In column 14, which is a gloss to one line in the Orphic poem, the Derveni writer adds: 'Orpheus gave the name, Moira, to phrónēsis, intelligence ... Even before Zeus was mentioned Moira, the intelligence of the god, existed, always and everywhere.' In column 15 he goes on: 'When one says that Moira has spun one is trying to express that the phrónessis of Zeus has fixed all things, present, past and future, as they must be born, exist and die.' One might be tempted with Merkelbach [another scholar on this topic], to claim a connection between the phrónēsis mentioned by the commentator of the Orphic poem and the noêsis of Diogenes of Apollonia or the Noûs of Anaxagoras. However it should be noted that the term phrónēsis has a meaning that is less abstract, less purely intellectual and philosophical than noēsis and noûs, and refers to the forewarned prudence which is the characteristic attribute of mêtis.4

The point here is that Gadamer might indeed be someone to look to regarding phrónēsis, for he seemed to understand the dark side of the term, the term's connection to cunning intelligence, to a kind of prudence of survival. Here is the description of given in Vernant and Vidal Naquet's work:

The boys [young soldier-citizens] had to practice a virtue sōphrosune: This involved walking in silence in the streets, hands hidden beneath their cloaks, never glancing to the right or left but keeping their eyes fixed on the ground. They were never to answer back, never to raise their voices. They were expected to show that, even where modesty was concerned, the male sex was superior to the female. Xenophon reports that they could be truly taken for girls. But in conjunction with

${ }^{44}$ Detienne and Vernant, Cunning Intelligence, 138. 
this chaste, reserved, as it were hyper-feminine demeanor, they had to do things that were normally forbidden: steal from the adults' tables, plot and scheme, sneak in and filch food without getting caught. In fierce collective fights in which no holds were barred - biting, scratching, kicking allowed - they were expected to demonstrate the most violent brutality, behave as total savages, attaining the extreme limits of the specifically male virtue known as andreia: the frenzy of the warrior bent on victory at all costs, prepared to devour the enemy's very heart and brain, his face assuming the frightful mask of Gorgo....

In the monolithic view of phrónēsis and sōphrosunē mentioned at the outset of the essay, the picture of phrónēsis and sōphrosunē constructed by its advocates would look, à la, say, Martha Nussbaum, like a scene of delicate considerations of nuances in a Henry James novel rather than the arresting picture Vernant and Vidal-Naquet reanimate through Xenophon, a picture with more affinities to Caravaggio's Medusa than to Henry James. Caravaggio's famous painting brings woman back into the scene. In a display designed to show that "the male sex is superior to the female," the young soldier-citizens of Sparta end up looking like Gorgons, feminine powers not preoccupied with temperance, prudence, and orderly behavior, but with "the most violent brutality." As Christopher Long explains, the story of phrónēsis and sōphrosunē is homologous to other ancient tales in which patriarchal dominion is established and wins legitimacy by a subversion of the feminine that arises out of an implicit recognition of feminine power. "Each of these stories articulates a dimension of the tragic dialectic of patriarchal dominion: a feminine power is subverted in a foundational act of decision designed to establish and consolidate patriarchal authority; this act of subversion then wins legitimacy by repression as it is designated inevitable and identified with the natural order of things. ${ }^{.45}$ This repression disguised as the natural order of things might be called phrónēsis and/or sōphrosunē. It's the seemingly gentlemanly veneer covering a horror show.

The usual response to uncovering the dark side of phrónēsis has been for people to disengage from dialogue, or to insist that one "forgive" Heidegger and/or Gadamer. The latter stance invokes a kind of common humanity, a insistence on recognizing that you and I, dear reader, would have been as weak, as accommodating to National Socialism, as careerist, as opportunistic, as intent on saving our own skins as Heidegger and Gadamer. An effective response to the common humanity position can

${ }^{45}$ LoNG, 67. 
be found in an exchange between between Geoff Waite and Catherine Zuckert about Gadamer. In the exchange, Zuckert defends Gadamer in ways that most of us can imagine, and she invokes Socrates in Gadamer's defense. Here is part of Waite's reply to Zuckert, and do not be thrown off by his use of "Waite" instead of the pronoun "I":

Let us not overlook one thing: Socrates was physically killed for his troubles, and Gadamer was neither physically killed nor otherwise "devastated." And if neither Waite nor Zuckert can know what they themselves would have done in Hitler's Germany, then they can at least attempt to know, or they can refuse to know, what Gadamer did: they can deem this knowledge relevant, or irrelevant, to understanding his philosophy; and on this basis, they can accept or reject the "reasonable philosophy" that Gadamer saved for its current posterity, its afterlife... ${ }^{46}$

Waite's response to Zuckert captures the concomitant point about phrónēsis and sōphrosunē: we can attempt to know, or refuse to know, what Xenophon's account might mean for understanding the dark nature of phrónēsis and sōphrosunē.

Título. O lado negro da phrónēsis: retomando a incompetência política da filosofia Resumo. Em sua Ética, Aristóteles relaciona sōphrosunē e phrónēsis como sinônimos. Praticamente na mesma época, Xenofonte fornece um registro empírico de como a sōphrosune era vista no contexto grego antigo. Temos uma descrição preocupante da sōphrosunē em ação, que deixa o leitor com uma outra imagem do significado desses dois termos chave em relação às bem estruturadas e pacificamente aceitas interpretações contemporâneas, especialmente da filosofia continental, que tenta estabelecer a phrónēsis e a sōphrosunē como fundamentos para uma ética e uma política respeitáveis. Filósofos como Martin Keidegger e Hans-Georg Gadamer se ocuparam profundamente da phrónēsis aristotélica (não da variante xenofôntica), mas foram incapazes de pôr em prática esse conhecimento nas instâncias ética e política de suas próprias vidas, fazendo-nos indagar por que os seguidores de Heidegger e Gadamer continuam a insistir em programas éticos com base na tradição heideggeriana e gadamérica da phrónēsis, em que Aristóteles suplantou Odysseus como figura mais representativa da phrónēsis e da sōphrosunē.

Keywords. Phrónēsis; sōphrosunē; Aristóteles; Xenofonte; prudência; Gadamer; Heidegger; nacional-socialismo; esoterismo.

${ }^{46}$ Gadamer's Repercussions, 286. 